\title{
濃度成層下での熱プルームによる成層現象 \\ Layered convection due to thermal plume in linear concentration gradient system
}

\author{
○正 鎌倉勝善（富山高専）正 平野博之（岡山理大） 正 尾添紘之（西安交通大）
}

Katsuyoshi KAMAKURA, Toyama National College of Technology, 13 Hongo-machi, Toyama 939-8630

Hiroyuki HIRANO, Okayama University of Science, 1-1 Ridai-cho, Okayama 700-0005

Hiroyuki OZOE, Xi' an Jiaotong University, Xi'an, 710049, China

\begin{abstract}
The double diffusive natural convection arises owing to the rate difference between thermal and solutal diffusions in a fluid containing temperature and concentration gradients. The double diffusive layered convection due to thermal plume in linear concentration gradient system was numerically studied at the Prandtl number $P r=6$, the Rayleigh number $R a=10^{7}$ or $10^{8}$, the Lewis number $L e=100$, and the buoyancy ratio $N=1.5$. Thermal plumes occur from the heat source on the bottom but stop the ascending owing to the concentration gradient. Then the plumes develop to the primary convection layer with time. The temperature in the primary convection layer increases with time, and second thermal plumes occur on the primary hot convection layer. Finally the second thermal plumes develop a secondary convection layer.
\end{abstract}

Key Words: Double diffusive convection, Layered convection, Concentration stratified layer, Thermal plume

\section{1.はじめに}

二重搪散自然対流は，温度および濃度勾配のある流体内 で熱と溶質の拡散の速さの違いから生じる複雑な対流現象 である。そのとき温度浮力は上向きに作用し，濃度浮力は 通常下向きに作用する。すなわち二重拡散自然対流は，熱 の拡散係数と物質の拡散係数に対する比 (ルイス数) と濃 度浮力の温度浮力に対する比（浮力比）とに大きく依存す る現象でもある。上昇流中における二重拡散現象は，ソー ラーポンド, 煙突からの煙, 火災, 火山での噴煙, ヒート アイランドなど，工学あるいは環境におけるいろいるな場 でみられる。そのような場合, 地面あるいは底面が加熱さ れると多数の熱プルーム（上昇流）が発生する。 また大気 あるいは水環境で濃度成層が形成されることもある，その ような場合に低面が加熱されると発生した熱プルーム中に は高濃度の溶質が含まれ，下向きの濃度浮力となりプルー 么は上昇を抑えられる。そのとき対流層ができたり下降流 が発生したりする (2)（2). またその対流層の上に二次的なプ ルームができ第二の対流層に発達することも考えられる。 ソーラーポンドでは二次熱プルームの発生が下層での蓄熱 性能を悪くしている ${ }^{(3)}$ 。ここでは二次二重拡散プルームに よる成層現象を 3 次元で数值解析した。

\section{2. 数値解析}

熱と物質の移動を伴う自然対流の無次元基礎方程式を 次に示す。

$$
\nabla \cdot V=0
$$
(2)

$$
\partial \eta \partial \tau+(V \cdot \nabla) V=-\nabla P+\operatorname{Pr} \nabla^{2} V+\left[0,0, \operatorname{PrRa}(\theta \cdot N C]^{\mathrm{T}}\right.
$$

$$
\partial \theta / \partial \tau+(V \cdot \nabla) \theta=\nabla^{2} \theta
$$$$
\partial C / \partial \tau+(V \cdot \nabla) C=\nabla^{2} C / L e
$$

また無次元パラメータは次のよらに定義した。

$\operatorname{Pr}=\frac{v}{\kappa}, R a=\frac{g \alpha\left(T_{h o t}-T_{\text {cold }}\right) h^{3}}{\kappa v}, N=\frac{\beta\left(c_{\text {max }}-c_{\text {min }}\right)}{\alpha\left(T_{h o t}-T_{\text {cold }}\right)}, L e=\frac{\kappa}{D}$

無次元変数は次のように定義した，

$$
X=x / h, \quad Y=y / h, \quad Z=z / h \text {, }
$$

$$
\begin{aligned}
U=u h / \kappa, & V=v h / \kappa, \quad W=w h / \kappa, \\
\tau=t \kappa / h^{2}, & P=p h^{2} /\left(\rho \kappa^{2}\right) .
\end{aligned}
$$$$
\theta=\left(T \cdot T_{\text {cold }}\right) /\left(T_{\text {hot }}-T_{\text {cold }}\right), \quad C=\left(c^{-} c_{\text {min }}\right) /\left(c_{\text {max }} c_{\text {min }}\right)
$$$$
\text { ここで } \tau \text { : 無次元時間, } \theta: \text { 無次元温度, } C \text { : 無次元濃度, }
$$

$\boldsymbol{V}$ : 速度ベクトル, $T_{\text {hot }}$ : 最大温度 (下面の加熱温度), $T_{\text {cold }}$ : 初期最小温度, $c_{\text {max }}$ : 初期最大濃度, c m min : 初期最小 漶度, $\alpha:$ 温度に関する体膨張係数, $\beta$ : 濃度に関する体膨張 係数, $v$ : 動粘性係数, $\kappa$ : 温度伝導率, $D$ : 㹡散係数, $h:$ 系の 高さである。基礎方程式Eqs. (1)-(4)をFig. 1 (立方体) の 初期市よび境界条件のもとで 3 次元の有限差分法で解いた。 ナビエ・ストークス式の圧力項はHSMAC法で, 全ての対流項 は 3 次精度の風上差分で計算した. 容器の大きさは $1 \times 1 \times 1$, 格子点は $101 \times 101 \times 101$ または $121 \times 121 \times 121$ (いずれも等間 隔）とし，下面全体を加熱した，下面は $\theta=1$ とし，系全域 での初期温度は $\theta=0$ とした。直線的濃度勾配 $(\partial C / \partial Z=1$, $C=0$ at $Z=1, C=1$ at $Z=0$ ) 初期濃度分布とした. すべての 面は固体壁とし，加熱面以外は熱と物質は通過しないとし た. $P_{x}=6, L e=100, R_{a}=10^{7} \sim 10^{8}, N=1.5$ として計算した。

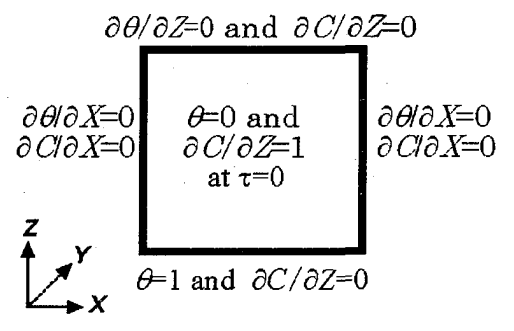

Fig.1 Initial and boundary conditions.

\section{3. 結果と考察}

Fig. 2 に $R_{a}=10^{7}$ における温度 $(\theta)$ 及び濃度等高線 $(C)$ を示す、濃度勾配のある系の下面を加熱することにより下 面から複数の熱プルームが発生した。 その複数の熱プルー ムが集合し凹凹のある界面が形成され対流層に発達した。 時間の経過と共にその対流層にはさらに熱が蓄えられ，几 凸のある界面の上に新たに温度成層が形成された，その温 度成層から二次的な熱プルームが発生した。この二次熱プ ルームは第一の対流層の上の第二の対流層に発達すると思 われる. しかし $R a=10^{7}$ では, 余り明確な第二の対流層では 
ない.

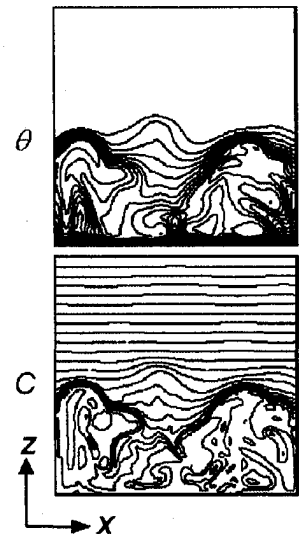

$\tau=0.006$

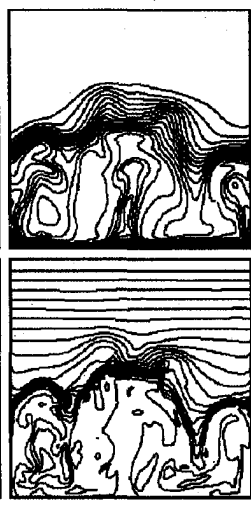

0.012

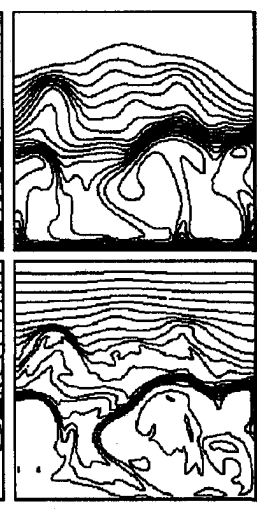

0.018
Fig. 2 Contour lines of temperature $(\theta)$ and concentration $(C)$ in $X Z$-plane at $Y=0.5$ for $R_{a}=10^{7}$.

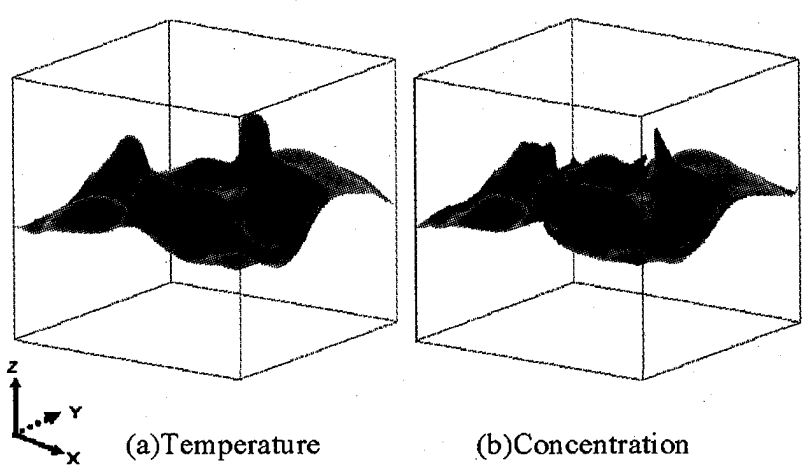

Fig. 3 Contour planes of temperature at $\theta=0.3$ and concentration at $C=0.5$ for $R a=10^{7}$ and $\tau=0.018$.

Fig. 3 に $\tau=0.018$ における温度および濃度等高面を示す。 下面加熱による下層での熱プルームにより凹凹のある界面 ができるが，さらに界面の凹凸の一部はさらに二次的な熱 プルームに発達している．時間と共に複数の二次プルーム が集合し，第二の次対流層に発展していくものと思われる.

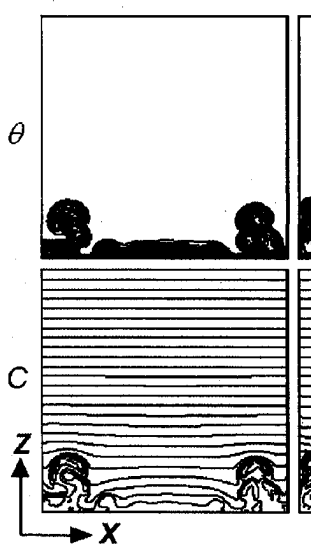

$\tau=0.00072$

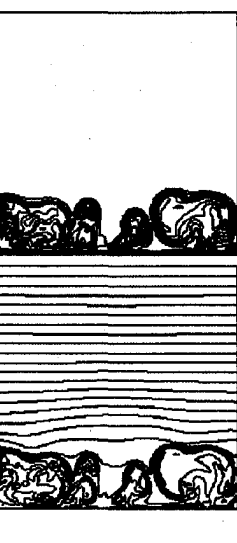

0.00088

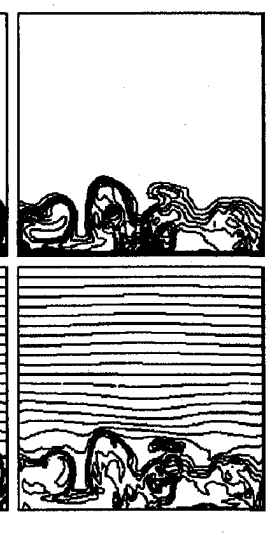

0.00104
Fig. 4 Contour lines of temperature $(\theta)$ and concentration $(C)$ in $X Z$ plane at $Y=0.5$ for $R a=10^{8}$.
Fig. 4 に $R=10^{8}$ の場合の温度及び濃度等高線を示す。レ 一リ一数は，温度差を一定とすると系の体積に比例する值 である。市なわち系の体積が大きくなっているので，熱プ ルームは $R a=10^{7}$ の場合より相対的にある低い高さまで上昇 し横に広がり第一の対流層となった。また側壁近くから中 心に向かって熱プルームが発生している.Fig. 5 に $\tau=0.00104$ における側壁近くの温度及び濃度等高線を示す. 側壁に近い温度等高線では，加熱下面での一次熱プルーム と第一の対流層上部での二次熱プルームの発生が明瞭にみ られる. $R a=10^{7}$ の場合と同様に，第一の対流層上部での複 数の二次熱プルームが時間と共に集合し，第二の対流層に 発展していくものと思われる。第一の対流層の界面は $R a=10^{7}$ の場合より平坦で鮮明である.
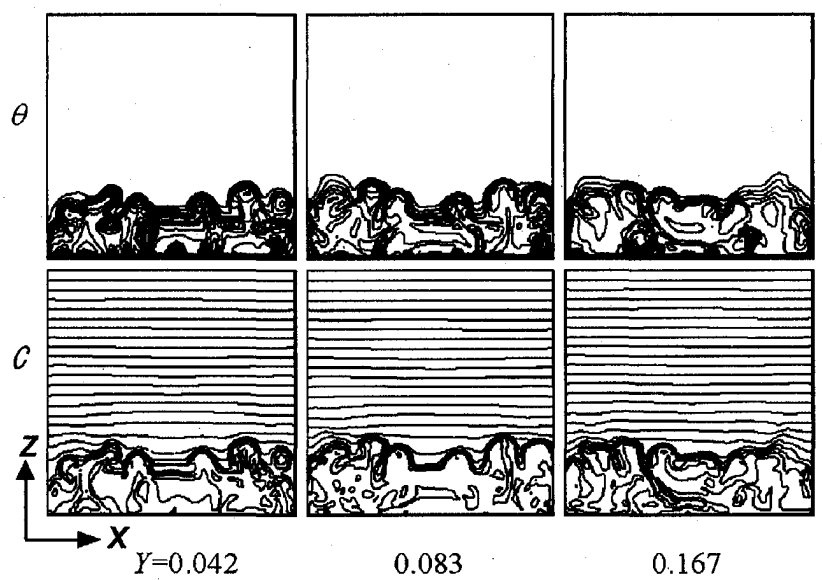

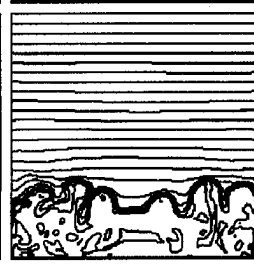

0.083

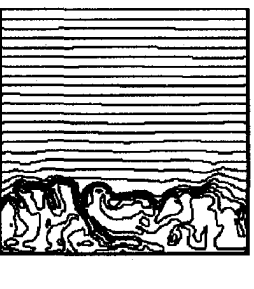

0.167
Fig. 5 Contour lines of temperature $(\theta)$ and concentration $(C)$ in $X Z$-plane at different $Y$-positions for $R a=10^{8}$.

4.まとめ

濃度勾配のある系の下面を加熱すると複数の熱プルー ムが発生し第一の対流層ができる，その対流層の温度は時 間の経過と共に高くなるので第一の対流層の界面の上に複 数の二次熱プルームが発生し，さらに第二の対流層へと発 展した。

\section{参考文献}

(1) Kamakura, K., Miyashita, H. and Ozoe, H., Numerical Analyses of Double Diffusive Convection in a Container Cooled from Top and Heated from Bottom, Proc. 6th KSME-JSME Thermal and Fluids Eng. Conf., Jeju, KD.07, 2005.

(2) Kamakura, K., Hirano, H. and Ozoe, H., Numerical analysis of ascending thermal plume in linear concentration stratification, 17th Int. Symp. on Transport Phenomena, Toyama, 2-C-IV-2, 2006.

(3) 鎌倉, 尾添, ソーラーポンドにおける二重拡散現象, 第 16 回環境工学総合シンポジウム, 東京, 2006. 